\title{
PROBLEMS IN THE DESIGN OF VARIETY TRIALS WITH SPRING CABBAGE
}

\author{
M. NIEUWHOF \\ Institute of Horticultural Plant Breeding, Wageningen \\ With 2 figures \\ Received 24 March 1959
}

\begin{abstract}
1. The differences in productivity between three strains of the spring cabbage Eersteling could be explained partly from a longer growing period and partly from a more rapid growth rate.

2. In commercial trials with spring cabbage only one spacing is needed to obtain a sufficiently reliable comparison of the various characters.

3. Commercial trials with spring cabbage arranged in a latin square with one plant per plot will usually give sufficient practical information on the measurable characters.
\end{abstract}

\section{INTRODUCTION}

The trials with spring cabbage reported here have been made in an attempt to solve two problems in the design of variety trials with this crop.

The first problem presented itself when in comparative trials with strains of the variety Eersteling these strains were grown at the same spacing, while there were fairly large differences in size between the various strains. It was considered that strains planted at different spacings would probably not all behave in a similar way. Therefore the effect of 4 planting distances on 3 strains of different size was ascertained.

The second problem concerned the question whether it is possible to plant some variety trials on a smaller field by arranging them in latin squares with one plant per plot, instead of in a normal replicated block trial, as this will often reduce variations in the soil conditions within the trial.

The author is indebted to the mathematical section of the Institute for advice and computations.

THE EFFECT OF DIFFERENT SPACINGS

\section{Trial design}

The distances chosen were $40 \times 40,50 \times 50,55 \times 55$ and $65 \times 65 \mathrm{~cm}$. The three strains of Eersteling were numbers 16 (with little spread), 11 (with medium spread) and 12 (with large spread) (fig. 1). The numbers of the strains correspond with those by which these strains were indicated in the commercial trials with spring cabbage in 1956 and 1957. By "spread" is meant the breadth of the plant measured across the head.

The trial was replicated twice using 48 to 52 plants per plot. Sowing was done in a 


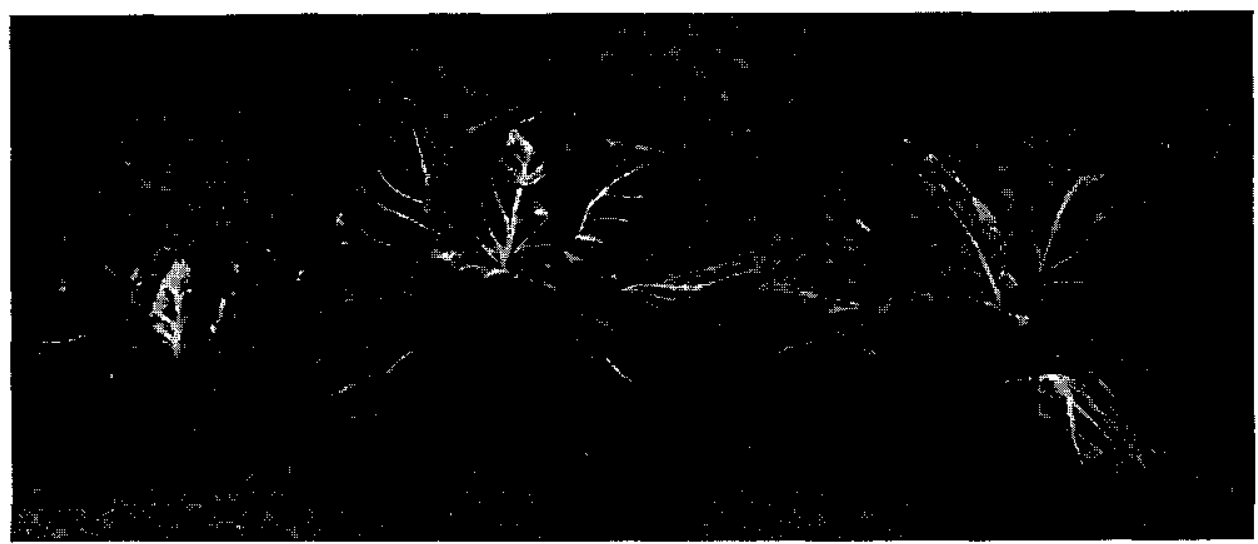

FIG. 1. THREE STRAINS OF THE SPRING CABBAGE EERSTELING WITH DIFFERENT SPREAD.

seedbed on 20 September 1956; the plants were overwintered under glass and planted in the open on March 22, 1957.

The gross and net weights of the heads were determined at the moment they were ripe for harvesting. The gross weight is taken to be the weight of the whole plant, i.e. the head and outer leaves together; the net weight is the weight of the head without the outer leaves.

\section{Results}

The net weight converted to $1,000 \mathrm{~kg}$ per ha in entered in table 1 . Between brackets are the relative yield figures, counting the yield from strain 12 as 100 .

TABLE 1. Net Yield IN 1,000 KG PER HA

\begin{tabular}{c|c|c|c|c|c}
\hline \multirow{2}{*}{ Strain number } & \multicolumn{6}{|c}{ Spacings (cm) } \\
\cline { 2 - 7 } & $40 \times 40$ & $50 \times 50$ & $55 \times 55$ & $65 \times 65$ \\
\hline \multirow{2}{*}{16} & $40.4(67)$ & $26.6(59)$ & $19.8(52)$ & $16.9(58)$ \\
11 & $43.4(72)$ & $34.0(75)$ & 30.1 & $(80)$ & $21.4(73)$ \\
12 & $60.0(100)$ & $45.2(100)$ & $37.7(100)$ & $29.2(100)$
\end{tabular}

It will be seen that for all strains the yield increases with closer spacings. At all four spacings the largest strain (number 12) is the most productive, while the relation between the yields of strains 12 and 11 remains of the same order (strain 11 produces $72-80 \%$ of the yield of strain 12). At the three widest spacings the relation between the yields of strains 12 and 16 is also practically the same (yield of strain 16 is $52-59 \%$ of that from strain 12). However, the $40 \times 40 \mathrm{~cm}$ spacing places strain 16 in a relatively more advantageous position, since it now produces $67 \%$ of the yield of strain 12 . Consequently at closer spacings the strains with little spread are relatively more productive.

The greater productivity of a strain is accompanied by a longer growing period. Thus the date on which $50 \%$ of the crop was harvested fell about 13 days later for 
strain 12 than for strain 16 , and $6 \frac{1}{2}$ days later for strain 11 than for strain 16 . The duration of the growing period in the field varied from 69 to 85 days.

However, the differences in productivity cannot be explained only from the growing period. There is also a difference in the average daily increase in weight. The average net increase in weight per day is expressed in $\mathrm{kg}$ per ha (table 2). Between brackets is given the relative increase in weight of the strains as compared with the increase in weight mentioned for the widest spacing.

TABle 2. AVERAGe NET increase in Weight PER DAY IN KG PER HA

\begin{tabular}{|c|c|c|c|c|}
\hline \multirow{2}{*}{ Strain } & \multicolumn{4}{|c|}{ Spacings } \\
\hline & $40 \times 40$ & $50 \times 50$ & $55 \times 55$ & $65 \times 65$ \\
\hline 16 & $553 \quad(229)$ & $380 \quad(158)$ & 287 (119) & $241 \quad(100)$ \\
\hline 11 & 536 (188) & 436 (153) & 401 (141) & $285(100)$ \\
\hline 12 & $706 \quad(203)$ & $538 \quad(155)$ & 461 (132) & $348(100)$ \\
\hline
\end{tabular}

At the three widest spacings the higher productivity (table 1) is accompanied by a larger increase in the net weight per day. Only at $40 \times 40 \mathrm{~cm}$ the daily increase of strain 11 is somewhat smaller than that of strain 16. That strain 11 at this close spacing nevertheless yielded about equally high as strain 16 is, therefore, only attributable to the longer growing period.

We have calculated that about $11 \%$ of the greater productivity of strain $12 \mathrm{com}$ pared with that of strain 16 is due to the longer growing period - the period between planting and harvesting -; for strain 11 about $5 \%$. Hence the differences in productivity are largely associated with the growth rate.

From the relative increase in weight it appears that as the spread of a strain becomes less the check in growth sustained by each individual plant at closer spacings also becomes less. However, the difference between strains 11 and 12 at the two closest spacings is only slight. This may be partly due to the fact that the difference in spread between these two strains is not very large either.

The effect of spacing on the individual plant also appears from table 3 , showing the gross and net weight per plant, the spread and the $50 \%$ harvesting date. The $50 \%$ harvesting date is the date on which $50 \%$ of the total crop is harvested.

Table 3. The average gross and Net Weight of the plant, the SPREAd and the Earliness

\begin{tabular}{|c|c|c|c|c|c|c|c|c|c|c|c|c|}
\hline \multirow{2}{*}{ Spacing } & \multicolumn{3}{|c|}{$\begin{array}{l}\text { Gross weight } \\
\text { per plant in kg }\end{array}$} & \multicolumn{3}{|c|}{$\begin{array}{c}\text { Net weight } \\
\text { per plant in kg }\end{array}$} & \multicolumn{3}{|c|}{$\begin{array}{c}\text { Spread in } \\
\mathrm{cm}\end{array}$} & \multicolumn{3}{|c|}{$\begin{array}{l}50 \% \text { harvesting } \\
\text { date days in June }\end{array}$} \\
\hline & 16 & 11 & 12 & 16 & 11 & 12 & 16 & 11 & 12 & 16 & 11 & 12 \\
\hline $40 \times 40$ & 0.86 & 0.95 & 1.26 & 0.65 & 0.70 & 0.96 & 39 & 40 & 41 & 3 & 11 & 15 \\
\hline $50 \times 50$ & 0.91 & 1.20 & 1.51 & 0.67 & 0.85 & 1.13 & 43 & 49 & 51 & 0 & 8 & 14 \\
\hline $55 \times 55$ & 0.86 & 1.39 & 1.60 & 0.62 & 0.94 & 1.18 & 41 & 48 & 52 & -1 & 5 & 12 \\
\hline $65 \times 65$ & 0.99 & 1.24 & 1.70 & 0.72 & 0.91 & 1.24 & 45 & 47 & 48 & 0 & 5 & 14 \\
\hline
\end{tabular}




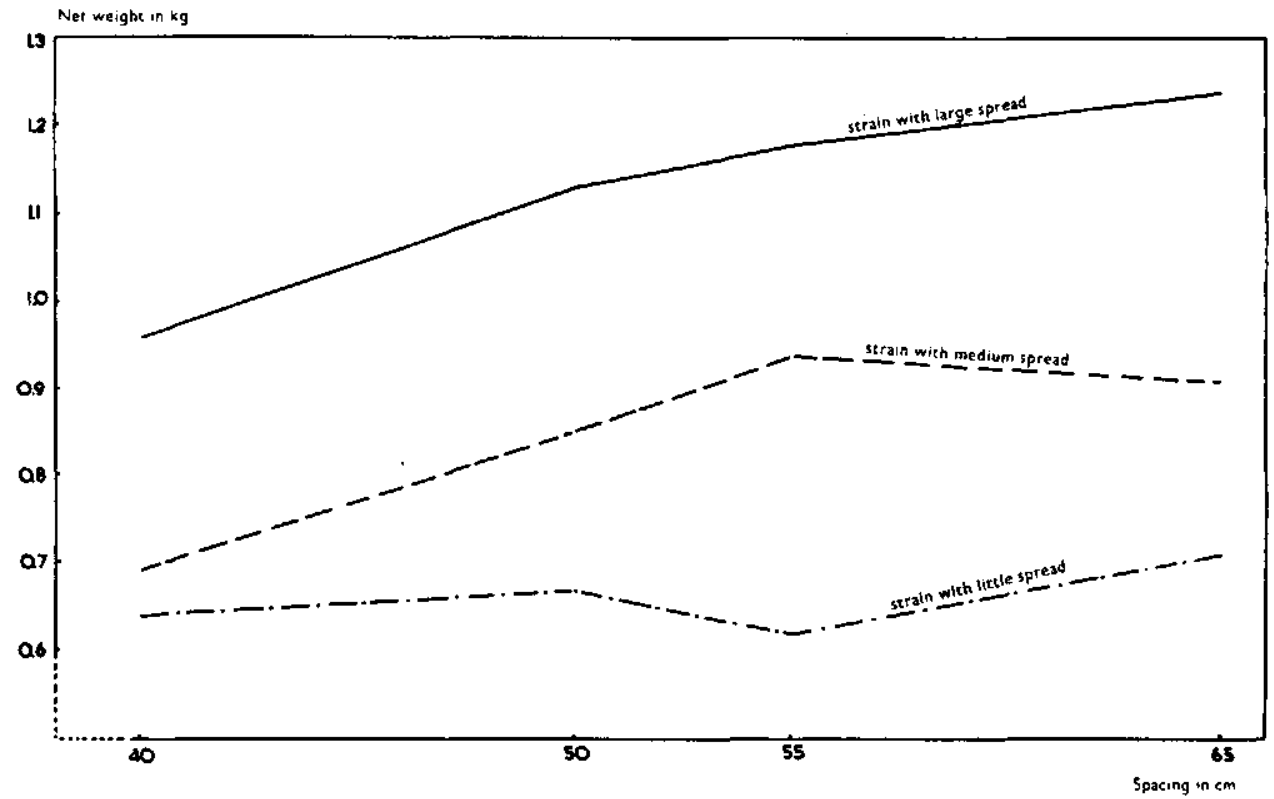

Fig. 2. Net YIELD PER PLANT OF THREe STRANNS OF EERSTELING FROM 4 SPACINGS

At closer spacings the growth of the plant is clearly checked (fig. 2). This is reflected in a smaller head, and slower growth - the head matures later.

\section{Discussion}

In variety trials it is necessary to choose such spacings as mask the principal characters of a strain as little as possible. We have seen that the relation between strains 11 and 12 regarding the net weight of the head was about the same at all four spacings. At the three widest spacings the relation between strains 16 and 12 was also about the same; at $40 \times 40 \mathrm{~cm}$ this relation changed somewhat in favour of strain 16 . So at different spacings the productivity relation between the various strains is not always alike, although it does not change to such an extent that it becomes necessary to test the varieties at more than one spacing. Using a spacing of at least $50 \times 50 \mathrm{~cm}$ it seems likely that a reliable comparison of the strains with a medium to fairly large spread can be obtained. Relatively, the strains with little spread are then judged somewhat too unfavourable, since at closer spacings their growth is retarded less than that of strains with a large spread, so that they become more productive.

\section{LATIN SQUARE}

In 1957 the results from a block trial of 21 strains in two replications with 33 plants per plot, were compared with those from a latin square with the same 21 strains, but using only one plant per plot. In these experiments the latin square gave a saving in space of $68 \%$. In both trials a $55 \times 55 \mathrm{~cm}$ spacing was used. The results are shown in table 4. 
THE DESIGN OF VARIETY TRIALS WITH SPRING CABBAGE

TABle 4. Standard deviations, COEFficients of Variation AND levels OF SIGNificance

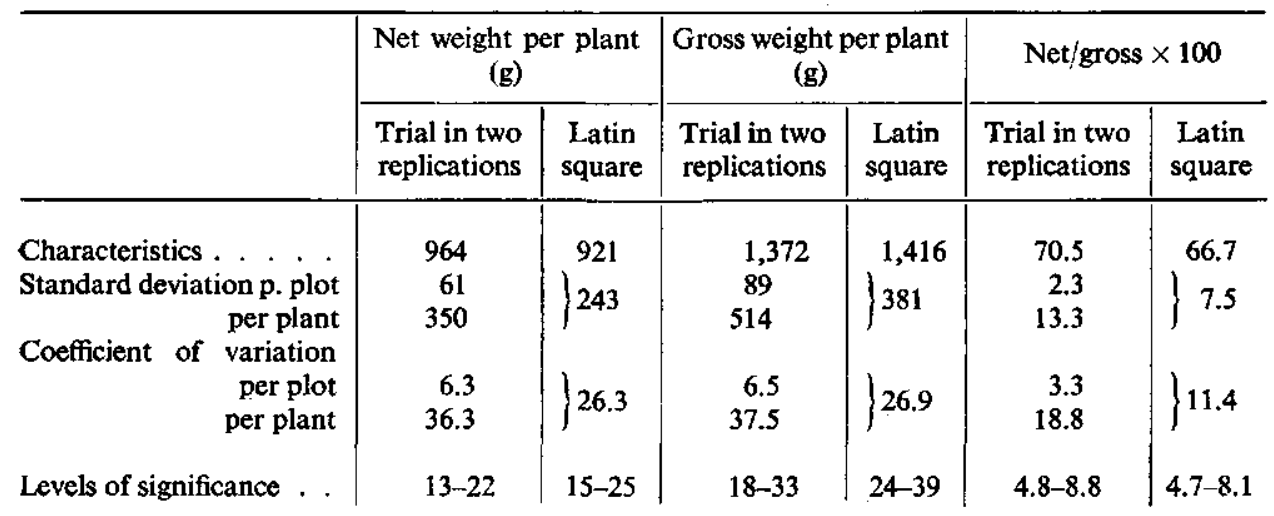

The averages do not differ much. In the trial in two replications the standard deviations of the plots are considerably smaller than in the latin square, as would be expected. In the former trial the standard deviation per plot equals $\sqrt{ } 33$ times the standard deviation per plant, while in the latin square it equals the standard deviation per plant. It is of importance that the standard deviation per plant is smaller in the latin square and consequently also the coefficient of variation per plant, for the latter is equal to the quotient of the standard deviation and the average times 100 . This may be partly due to the smaller growing area occupied by a latin square arranged in this manner. Any fluctuations in the soil conditions are then smaller.

The latin square has a smaller coefficient of variation than a block trial in two replications. Hence the latin square makes it possible to demonstrate a difference with a smaller number of plants than that required for the block trial. In our case the confidence limits at the 5 per cent level are about the same for the latin square with 21 plants per strain as for the trial in two replications with 66 plants per strain.

\section{Discussion}

In judging commercial trials with spring cabbage one is concerned with measurable characters. It seems justified to arrange such trials, at least the simple yield trials, in latin squares using one plant per plot. For eye judgement it will also be necessary to plant a normal block with 30 to 50 plants per plot.

The latin square has the disadvantage that its lay-out, especially in the beginning when one has not yet much experience with it, will take a little more time. Moreover its application will only be possible if the number of varieties to be tested is not too small, while the adventage of the saving in growing area becomes smaller as the number of varieties to be tested increases.

\section{SAMENVATTING}

\section{Proeftechnische aspecten bij rassenproeven met spitskool}

1. Het verschil in productiviteit tussen drie selecties van het spitskoolras Eersteling is deels het gevolg van een langere groeiperiode en deels van een snellere groei. 


\section{NIEUWHOF}

2. Bij praktijkproeven met spitskool is bij één plantafstand een voldoend betrouwbare vergelijking van de verschillende eigenschappen mogelijk.

3. Praktijkproeven met spitskool opgezet als latijns vierkant met één plant per veldje zullen voor praktijkdoeleinden meestal wel voldoende gegevens verschaffen over de meetbare eigenschappen van de selecties. 


\section{PUbLICATIONS OF THE INSTITUTE OF HORTICULTURAL PLANT BREEDING}

The following publications can be obtained in one of three ways:

a. by ordering them from the Institute of Horticultural Plant Breeding (I.V.T.), P.O. Box 16. WageningenNetherlands

$b$. by sending in exchange publications that are of interest to the I.V.T.

c. by borrowing them from the I.V.T. library

Rassenlijsten/Variety lists

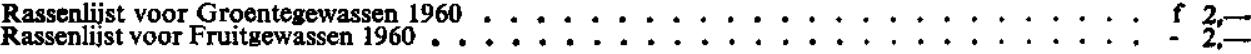

Rasbeschriivingen/Varietal Descriptions

1. Jensma, J. R. Cabbage varieties/Sluitkoolrassen, (only for sale) . . . . . . . . . . . f 13,50

2. Leemans, J. A. and E. T. Nannenga, Raspberry varieties, (only for sale) . . . . . . - 25,-

Mededelingen/Communications

106. Andeweg, J. M. and J. H. Ruyten. Seven years experience with hybrid tomatoes. Juni 1957

106. Ander. J. M. 0.50

108. Banga, O. Horticultural plant breeding in the Netherlands. Juni $1957 . \ldots$

109. Giessen, A. C. van der and A. van Steenbergen. A new method of testing beans for Anthracnose. Juni 1957

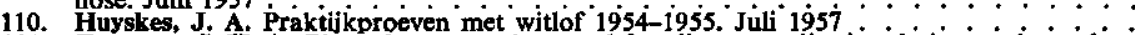

111. Ferguson J. H. A. Photothermographs a tool for climate studies in relation to ${ }^{\circ}{ }^{\circ} \dot{b}^{\circ}$

Sneep, J. Geschiedenis van de spinazie en het ontstaas van de rassen. Óktober i9 $\dot{3}^{\circ}$.

112. Sneep, J. Geschiedenis van de spinazie en het ontstaan van de rassen. Oktober $1957.95 j$

113. Sneep, J. De stand yan de veredeling bij spinazie. Dissertatie, Wageningen, november 1957 1957 . M. en A. v. Steenberzen. Praktijkproeven met pronkbonen 1955-1956. Óktober 1957

116. Garretsen, $\dot{\mathbf{F}}$ en H. G. Kronenberg. Opbrengstoroeven met żarte bessen. Oktober 1957

116. Garretsen, F. en H. G. Kronenberg. Opbrengstproeven met zwarte bessen. Oktober 1957 . Bruyn, J. W. de. Het gehalte aan mydriatische alkaloiden van Scopolia lurida. Oktober 1957

119. Floor. J. Verslag van proeven met stekken onder waterneveling. Oktober 1957 . P and A. E. Zeilinga. Production of a colchicine-induced tetraploid asparagus. December 1957

120. Andewes. J, M. and A. van Kooten. The practical importance of an identification of garden pea varieties in the seedling stage. December 1957 . Banga, O..J. W. de Bruyn en J. L. van Bennekom. Praktijkproeven vroege kroten 1955-1956. Banga, $O$. Effect of some environmental factors on the carotene content of carrots. Januari 1958

123. Elzenga, $\dot{G}$ ' Influence of external factors on the alkaloid content in some medicinal plants. Januari 1958 . J. Zjjn er in Nederland mogelijkheden voor de teelt van buitenperziken. FeGerritsen. C. J. Zijn er in Nederland mogelijkheden voor de teelt van buitenperziken. Fe Nieuwhof, M. en A. Kraai. Praktijkproeven met spitskool 1956-1957. April 1958 : : : Gerritsen, C. J. De tamme kastanje een fruitgewas? April 1958 .
Kronenberg, H. G. en B. Roelofsen. De teelt van aardbeien en frambozen in Schotland. Juli 1958

Herysk

130 . Kragi A Bijen Het kweken van zwaardere glasslarassen. juli

131. Banga, $\boldsymbol{O}$. and $J$. Petiet. Breeding male sterile lines of Dutch onion varieties as a preliminary

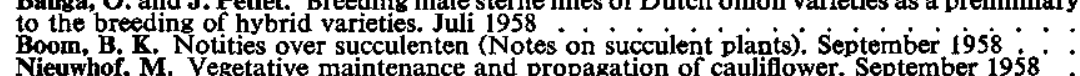

133. Nieuwhof, $\dot{M}_{\text {. Vegetative maintenance and propagation of cauliflower. September } 1958^{\circ}}$ ment. September 1958

135. Braak, J. P and Y, O. Kho. Some observations on the floral biology of the carrot (Daucus

136. Gerritsen. C.J. De teelt van abrikozen. September 1958

137. Nieuwhof, M. Ervaringen op het I.V.T. met de veredeling van spitskool. Januari 1959 :

138. Nieuwhof, M. en A. Kraai. Praktijkproeven met het bloemkoolras Lecerf 1956-1957. .

139. Gerritsen, C. J. De Amandel. Februari 1959 .

140. Huyskes. J. A. Praktijkproeven met herfst-en winterprei 1955 en 1956 . Februari 1959 .

141. Banga, O., J. W. de Bruyn, J. L. van Bennekom en H. A. van Keulen. Selection of carrots for carotene content. IV Reduction of the gas exchange of the soil. Maart 1959:

142. Wiering, D. Artificial pollination of cabbage plants. Maart 1959 . ${ }^{2}$.

143. Rodenburg, C. M. The identification of lettuce varieties from the young plants. Maart 1959

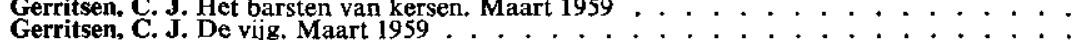
Gerritsen, C. J. De vijg. Maart 1959 . . .

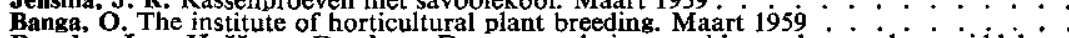

148. Douglas, J. en $\mathbf{H}$. H. van Doesburg. De vermeerdering van blauwe bessen door middel van scheutstekken April 1959

149. Gerritsen, C. J. Een hoger rendement bij de teelt van hazelnoten. Mei $1959^{\circ}::^{\circ}:$ :

150. Andeweg, J. M., and $\mathbf{J}$. W. de Bruyn. Breeding of non-bitter cucumbers. Juli $1959^{\circ}$.

151. Huyskes, J.A. A method for selecting asparagus varieties with a long fibreless top. Juli 1959 Bruyn, J. W. de, en J. G. van Hall. De bepaling van kleine hoeveelheden hyoscyamine en

153. Nieuwhof, M. Some experiences with the breeding of pointed headed cabbage. November 1959

154. Nieuwhof, $M$. Problems in the design of variety trials with spring cabbage. November 1959

155. Szteyn, $\mathbf{K}$. Trials to overcome the incompatibility of crosses between Lycopersicum esculen-

156. Huyskes, J. A. The value of comparative tests of progenies from open-pollinated fernale
asparagus plants. November 1959 . 


\title{
INSTITUUT VOOR DE VEREDELING VAN TUINBOUWGEWASSEN
}

\author{
Institute of Horticultural Plant Breeding \\ DIRECTOR: DR. O. BANGA \\ ASSISTANT DIRECTOR: IR. J. GROENENDIJK
}

15 Dr. S. L. Mansholtlaan, Wageningen, The Netherlands. Telephone 3141

The general purpose of the Institute is the improvement of horticultural plants, inclusive of tobacco, and the investigation of problems in this field and in related ones.

It works under a board of plant breeders and growers, and is supervised by the Ministry of Agriculture.

The activities of the Institute comprise:

1. Research on varieties of horticultural plants:

a. General documentation

b. Plant introduction

c. Distinctive characters

d. Cultural value

2. Research on methods of horticultural plant breeding and, as far as necessary, breeding work itself.

3. Research on seed growing and vegetative propagation.

4. Advisory work in these fields.

\section{Members of Staff:}

Breeding methods and special crops (including bulb and root crops): Dr. O. Banga; Ornamentals: Ir. J. Groenendijk (temporary).

'Boskoop'crops: Ir. F. Schneider (stationed at Boskoop Research Station for Arboriculture).

Tomatoes, cucumbers etc.: Ir, J. M. Andeweg and Ir. K. Szteyn;

Herbs and tobacco: Ir. G. Elzenga, Ir. L. F. J. M. van der Ven (guest associate);

Leafy vegetables: Ir. J. A. Huyskes;

Pulses: Ir. E. Kooistra;

Cabbage crops: Ir. M. Nieuwhof;

Disease resistance tests: A. C. v. d. Giessen.

Tree fruits: Ir. A. S. de Bruyne;

Small fruits: Miss Ir. H. G. Kronenberg.

Floral Biology: Drs. J. P. Braak, Ir. Y. O. Kho and A. E. Zeilinga;

Physiology: Ir. L. Smeets;

Mathematical statistics and climate ecology: Ir. J. H. A. Ferguson;

Phytochemistry: Drs. J. W. de Bruyn;

Taxonomy of ornamental plarts and street trees: Dr. B. K. Boom;

Taxonomy of fruil crops: Drs. E. T. Nannenga.

Visitors: G. Komen.

Publications: W Koopmans.

Matters concerning Plant Breeder's Right and Plant Introduction: W. E. G. de Bruin.

Secretary: R. Vos.

Accountant: J, W. van Eyndhoven. 